\title{
Is intelligent design science, and does it matter?
}

\author{
P W Bateman \\ (University of Pretoria) \\ $\mathrm{J}$ M-Ellis \\ (University of Surrey)
}

\section{ABSTRACT}

\section{Is intelligent design science, and does it matter?}

The debate between evolution and intelligent design is usually presented by evolutionary biologists as a clash between science and non-science (creationism and religion) and therefore as a sterile argument which science wins by default. Countering this is intelligent design (ID) and irreducible complexity (IC) which posit that the diversity and complexity of life on earth indicates the hand of a designer, although the nature of that designer is not speculated on. In doing so, proponents of ID and IC bring the argument squarely into the scientific camp and fulfil the requirements of being science, although this is difficult to define. Here, we discuss the claims of ID and IC to provide an alternative to evolution and propose that science can adequately deal with and refute these claims. At the same time, ID and IC fulfil an important role as foils to 'scientism' - the belief that science is the best way of answering all questions. In the final analysis, however, despite their value in the debate, ID and IC are not found to be robust or reliable enough to replace evolution as the best way of explaining the diversity of life on earth.

\section{SCIENCE VERSUS RELIGION?}

Science and religion are apparently in a death lock, at least in the school houses and court rooms of the U.S.A. The attempts by the proponents of Intelligent Design (ID) to have it taught alongside evolution in science classes received a knock-back on the $20^{\text {th }}$ December 2005 as the Kitzmiller et al. v. Dover Area School District Court Judge John Jones III decided that ID is 'not science' but 'religion' and therefore not suitable for science classes in secular schools. The judgement made by Judge Jones III and the comments of scientists who uphold evolution as 'correct' i.e. as a paradigm, both construct the challenge to the credibility of ID as a straightforward clash between religion and science - between 'revealed truth' and 'empirical evidence'. Supporters of evolution 
uphold its explanatory superiority on the basis of its grounding in the scientific method which is

... the organized, systematic enterprise that gathers knowledge about the world and condenses the knowledge into testable laws and principles (Wilson 1998:57, original emphasis).

For proponents of evolution, it is a proven theory which can account for the diversity of life on earth. To clarify what is meant by the apparently oxymoronic 'proven theory' it is worth quoting the evolutionary biologist Stephen Jay Gould (1983:254) at length:

Well evolution is a theory. It is also a fact. And facts and theories are different things, not rungs in a hierarchy of increasing certainty. Facts are the world's data. Theories are structures of ideas that explain and interpret facts. Facts don't go away when scientists debate rival theories to explain them. Einstein's theory of gravitation replaced Newton's in this century, but apples didn't suspend themselves in midair, pending the outcome. And humans evolved from ape-like ancestors whether they did so by Darwin's proposed mechanism or by some other yet to be discovered.

Moreover, 'fact' doesn't mean 'absolute certainty'; there ain't no such animal in an exciting and complex world. The final proofs of logic and mathematics flow deductively from stated premises and achieve certainty only because they are not about the empirical world.

Evolutionists make no claim for perpetual truth, though creationists often do (and then attack us falsely for a style of argument that they themselves favor). In science 'fact' can only mean 'confirmed to such a degree that it would be perverse to withhold provisional consent'.

\section{INTELLIGENT DESIGN AND AN INTELLIGENT DESIGNER}

Creationists counter this by claiming a different paradigm for understanding the existence of life on earth; that of special creation by a god. It is important to differentiate between different proponents of creation: strict creationists (who believe that the earth is 6 to 10,000 years old and that the earth and life was made in six 24 hour 
periods) are 'young-earth creationists' (YECs). There are also strict creationists who interpret 'days' as 'ages', or believe that the Bible refers to a 'gap' in the creation process, and are thus able to embrace the idea of an ancient earth: these are 'old-earth creationists' or OECs. If, however, one accepts evolution as the method by which the Creator produces life, then one is a 'theistic evolutionist'. This gradation is important: between the YECs and OECs, and those who support evolution with no god sit the theistic evolutionists who are proponents of Intelligent Design (ID). Between Creationists who draw on literal readings of the Christian Bible to provide an account for 'how things are', and scientists support evolution sit proponents of ID (ID-ers). Drawing on claims to be grounded in the scientific method qua evolution, ID-ers point to the existence of certain features of life such as the eye or the mammalian blood clotting mechanism which, they argue, cannot have arisen through an evolutionary process. In short, there are forms and features of living organisms which are irreducibly complex. We will examine this argument in more detail later in the paper but suffice it to say at this point that by making this claim, ID challenges evolution as a fact, whilst leaving the theory of evolution, i.e. the mechanisms by which form and/or function changes, intact. On this basis they deduce the existence of an 'Intelligent Designer' who created these features in their entirety and challenge the paradigmatic status of evolution. At the same time it is not technically within the remit of ID to propose a divine creator in as much as the 'Intelligent Designer' need not be a deity let alone the Abrahamic God. Shermer (2005) points this out very neatly:

When Intelligent Design Theorists use science to go in search of their God, what they will find (if they find anything) is an alien being capable of engineering DNA, cells, complex organisms, planets, stars, galaxies, and even universes. If we can engineer genes, clone mammals, and manipulate stem cells with science and technologies developed in only the last half century, think of what an ETI [extra-terrestrial intelligence] could do with, say, 10,000 years of such science and technology. Since IDers say they make no claim on who or what the intelligent designer might be, I contend that if they continue to try to reconcile their religion with science the 
end result can only be the discovery of an extra-terrestrial intelligence and the naturalization of their deity.

However, ID-ers almost certainly do locate their stance in their faith (for example, the U.S. think tank 'The Discovery Institute' conducts a campaign to support ID and says it aims to

reverse the stifling dominance of the materialist worldview, and to replace it with a science consonant with Christian and theistic convictions <http://www. discovery.org/> accessed 12/1/07).

Thus, the religious Christian link is strongly drawn through the individual religious commitments of those who support ID as an explanation of organic form and function and weakly drawn as an implication in the theory of a designer with supernatural powers. However the ID argument itself is couched in the language of science rather than belief. This brings us to the focus of this paper given that ID uses the conceptual apparatus of science to make its challenges to evolution, why do those who rebut the challenges see this as a matter of a battle between religion and science over which should frame the truth about life on earth? Why is this seen as a theistical/atheistical dualistic clash and not as two scientific paradigms in conflict with each other despite the efforts of ID supporters to frame their challenge as a scientific one? In order to explore this conundrum we will examine the claims and counterclaims made by proponents and opponents of ID, alongside the Judge Jones judgement.

\section{THE PRESENCE OF RELIGION IN THE ARGUMENT ABOUT LIFE ON EARTH}

The origin of evolution as a theory is inextricably bound up with religion in as much as the proposition put forward by Darwin that all species have evolved through a process of natural selection was received at the time as a denial of the Biblical account of the creation of the world in Genesis, the obliteration of the hand of God in the creation of the world, and the implication that Homo sapiens is just another species derived from common ancestors with all other living organisms. Thus at the very start evolution was in potential conflict with certain forms of Christian thinking about life on earth. This is not to imply that all Christians reject evolution; for example the Catholic Church through the pronouncement of Pope John Paul II 
accepted the process of evolution as 'more than just a hypothesis' in a statement to the Pontifical Academy of Sciences in October 1996.

The relationship between religion and science continues to figure strongly (although negatively) for some scientists. Richard Dawkins, an evolutionary biologist and Professor of the Public Understanding of Science at Oxford University, vigorously states his position as an atheist, rejecting religious thinking and uncoupling science from the same. Holding an extreme view he says that evolution, as proposed by Darwin in 1859, finally allowed one to be an "intellectually fulfilled atheist" (Dawkins 1986:5) (although many would contend that philosophy had this role long before evolution). Addressing what he sees as the competing claims of science and religion to truths, he states that science is superior as it "regularly persuades converts of its superiority" (Dawkins 2003a:15). He has an over-all view of all religion as a dangerous 'brain virus' (Dawkins 2003b:137) and that teaching it to children is effectively child abuse (Dawkins, 2001; Dawkins, 1997).

Less extreme views exist, for example both Darwin himself, and the prominent evolutionary biologist John Maynard Smith considered themselves agnostic in the sense that knowing whether God exists or not is in principle impossible: to be truly scientific (in the sense of having empirical evidence) one then has to be agnostic; a word coined by 'Darwin's Bulldog', Thomas Huxley, in irritated response to dogmatic statements by both atheists and theists. The link between science and religion here is concerned with what it is that science can shed light on. The project of science to generate knowledge through a specific practice of empirical hypothesis testing cannot address the question of whether or not God exists. The matter of God's existence is primarily a matter of faith and belief (setting aside here the concept of the Bible and personal spiritual encounters as 'evidence'). Others, such as Francis Collins, Director of the U.S. Human Genome Project not only believes in God but says, "the scientific and religious world views are not only compatible but also inherently complementary” (Collins 2003:142).

The question of what religion and science can or should address, and the conflict when they aim to address the same questions has led some, as we see with Dawkins, to evict religion from the debating arena. Others like Collins seek to evict the notion of a conflict. A third response is to separate out the questions appropriate for religion from those appropriate for scientific 
investigation. Stephen Jay Gould has made such a move. In 1999 he produced a slim book ('Rocks of Ages: Science and Religion in the Fullness of Life') in which he expressed his view that, while he could not see how the two world views could be unified under one common scheme of explanation he could "not understand why the two enterprises should experience any conflict” if they stayed within their respective epistemological territories. Gould contended that 'Science' and 'Religion' each occupy a 'magisterium', i.e. a domain of authority in teaching and knowledge under which debate and dialogue can legitimately take place using appropriate discourses and methods. The territory of science is that of the empirical universe, whilst that of religion is the domain of moral meaning and values. Gould argues for a principle of 'Non-Overlapping Magisteria' (NOMA) for Science and Religion, since problems only arise when a magisterium trespasses on the territory of the other. The resolution of the potential for conflict then is in other words to be found in "render[ing] therefore unto Caesar the things which be Caesar's, and unto God the things which be God's" (Lk 20:25). Here religion is not evicted from the realm of debate, rather it is corralled into its appropriate realm, and credibility is accorded to the insights each magisterium contributes to questions about which they should rightly be concerned. This is, on first view, a compelling and comforting compromise, but it has received some criticism: Johnson (1999) says

...Gould condescendingly offers to allow religious people to express their subjective opinions about morals, provided they don't interfere with the authority of scientists to determine the 'facts' - one of the facts being that God is merely a comforting myth.

From the other side of the spectrum, Dawkins says “...does the fact that science cannot answer it [any particular enquiry] imply that religion can [?]” (Dawkins 2006:56).

So, the interplay between religion and science in the question of evolution is long-established. The desirability of this coupling is highly contentious for some scientists, whilst others seek to circumscribe the role of each in providing understandings of the world.

The ID challenge takes a different approach. It seeks to unify science and religion on the basis that science in respect of evolution 
fails to account sufficiently for certain phenomena which ID identifies as 'irreducibly complex'; accounting for these can only be done through a design inference (Dembski 1998). The argument made by ID draws on scientific discourses and empirical observation in an attempt to persuade the scientific community of the correctness of the conclusion that evolution is not a meta-theory, and that the hand of a Designer should neither be obliterated nor sidelined in explanations of biological form and function. We now look at this side of the debate: can ID lay claim to scientific credibility? If it can, what are the implications?

\section{PRESENCE OF SCIENCE IN THE ID ARGUMENT}

In a debate between sociologist Professor Steven Fuller and biologist Professor Jack Cohen of Warwick University (U.K.), Cohen said that "ID is religion in the robes of science" (<http://www. podcastdirectory.com/podshows/339033> accessed 10/12/06), with the implication that ID is an ideology and not science and therefore cannot effectively debate with science. This is almost certainly what Richard Dawkins would agree with, along with many other evolutionary biologists and other scientists. It is also the core argument of Gould's NOMA. But we feel that what we have here are two approaches to the same question (not NOMA) and a deliberate attempt by one side (creationism as ID) to argue in the language of the other (science).

\section{IRREDUCIBLE COMPLEXITY - SUPPORT FOR ID?}

In 1996, ID aimed to enter the scientific realm with the publication of a book by a biochemist from Lehigh University (U.S.A.): 'Darwin's Black Box: The Biochemical Challenge to Evolution' by Michael Behe. In his book Behe take ups the old argument of inference of design in nature on the basis of observed complexity which has been around since at least the $13^{\text {th }}$ century (as one of St Thomas Aquinas' five proofs of the existence of God in Summa Theologiae) and subtly modernises it. William Paley (1802) is, perhaps, the best known previous proponent of this argument. In his famous example, a rock found upon a heath might be assumed to have been there for all time, but a watch upon the heath, with its complexities, indicates that it has been designed, made and placed there. How much more, then, do the complexities of natural things, such as the eye, indicate the presence of design and hence a designer? Behe readdresses these questions in the light of work 
which has shown an evolutionary process in respect of the eye and other apparently complex systems. He has no problem with natural selection and evolution at the level of things like the eye, or evolution of feathers from scales for instance, but claims that natural selection falls apart at the cellular and biochemical level. Things such as the flagellum of a bacterium or the cascade of chemical reactions that result in blood clotting are, Behe says, irreducibly complex (IC). By this he means that each component of the flagellum and each stage of the chemical cascade are vital to the function of the whole, and therefore, given that they could not have appeared through one lucky mutation, one must infer a designer. The simple example that Behe uses as a starting point is that of a mouse trap consisting of a platform, a spring, a catch, a holding bar and a mouse-killing hammer. Take away any one part of the whole and you have something that cannot be used for trapping mice. Four separate elements are vital to the function of the trap, which is, therefore, irreducibly complex. Through this approach Behe explicitly draws on the methods of science: proposing a hypothesis, seeking empirical evidence in respect of that, and deriving a conclusion from an analysis of the evidence. Furthermore, as a biochemist who works on the evolution of chemical pathways, and as one who used to subscribe fully to evolution, Behe's credentials and approach to the question are unarguably scientific, even to the extent where he denies that IC is unfalsifiable and, therefore, by a rigorous demarcationist application of the definition of science would fail as a 'true' science. The evolutionist Kenneth Miller (1999:62) pointed out that to test IC one could use molecular genetics to

wipe out an existing multiple-part system and then see if evolution can come to the rescue with a system to replace it.

He then goes on to describe an experiment that apparently showed this, concluding "Behe is wrong” (Miller 1999). Behe responded to this, firstly by disagreeing with Miller's contention, but also by pointing out that Miller had shown how IC could be tested empirically and potentially falsified (Behe 2000).

There are, however, many problems with the concept of IC, and with Behe's argument as far as proponents of evolution are concerned and as evolutionary biologists believe that they can deal 
with them quite satisfactorily (by their lights, if not by Behe's and other ID-ers) it is worth examining these problems in some detail.

Each time IC comes up with a new 'irreducible' example, evolutionary biologists have to show how evolution could have done it, and, in turn, proponents of IC have to show how evolution, as we currently understand it, could not result in complex 'irreducible' structures and processes. This dialogue has produced some fascinating exchanges - far more complex and challenging than the evolutionary chestnut of the eye (an example that Behe believes is the result of an evolutionary process). Steven Meyer, of the Discovery Institute, sums up one of the better known examples thus:

Over the last 25 years, biologists have discovered an exquisite world of nanotechnology within living cells complex circuits, sliding clamps, energy-generating turbines and miniature machines. For example, bacterial cells are propelled by tiny rotary engines called flagellar motors that rotate at speeds up to $100,000 \mathrm{rpm}$. These engines look as if they were designed by the Mazda corporation, with many distinct mechanical parts (made of proteins) including rotors, stators, O-rings, bushings, U-joints and drive shafts...the flagellar motor depends on the coordinated function of 30 protein parts. Remove one of these necessary proteins and the rotary motor simply doesn't work. The motor is ...irreducibly complex (Meyer 2006).

Dorit (1997) in a review of Behe's book in American Scientist lists several fallacies in the IC argument which neatly summarise the evolutionist response, some of which we will cover briefly here: Fallacy 1) "there is a boundary between the molecular world and other levels of biological organization". Here Dorit means that Behe cannot argue for evolution at one level (eyes, feathers etc) and then claim to be stumped at the molecular/cellular level. The same rules of natural selection apply at all biological levels, and at the molecular level one may even be able to identify particular genes responsible - something not likely to be possible when studying the evolution of complex behaviour patterns in the whole organism for instance (which Behe seems to accept indicate evidence of evolution). 
Fallacy 2. "The current utility of a given feature (molecular or otherwise) explains 'why' the feature originally evolved". Here Dorit means that the proteins, for instance, involved in a particular process may not have started off in that role. Evolution, as Steven Jay Gould has constantly reminded us, has to 'gerrymander' with whatever it can use. Gould's (1980) famous example is the panda's 'thumb': a bone (the radial sesamoid of the wrist) that has become extended and adapted (like an extra digit) to strip leaves off bamboo shoots. Gould's point is that the bone has not arisen de novo and that poor design is better proof of evolution that good design. In Dorit's neat analogy evolution is a Third World car repairer who makes do with what is found lying around the garage forecourt to fix the vehicle, not a First World engineer who can machine-tool new parts.

These examples illustrate how the scientific process works, and here IC fulfils its role as a scientific argument/foil to evolution. Behe himself makes no claims on who or what the 'Designer' is and, in an interview (Wieland 1998), made his stance very clear:

The Darwinian mechanism...does not look like it can produce what it claims to be able to produce.

As far as descent from common ancestors is concerned, he says,

The idea of common descent has some support, and also some problems. Right now, I am willing to accept it as a reasonable working hypothesis, but I could always change my mind.

This sounds, to us, like a perfectly acceptable scientific viewpoint. Evolutionary biologists, however, believe that they can effectively counter the arguments of ID and IC, and in this way they strengthen their theory. Therefore, ID that uses IC as one of its arguments is not 'religion dressed in the robes of science'; it is not a magisterium that dares to overlap another; rather it is another approach to the same question but one that uses the same methodology in approaching the question. Anyone who believes that evolution is the best explanation we currently have for the diversity of form and function that can be seen around us would see ID as a failed theory because it cannot demonstrate in the first instance examples of irreducible complexity. However, at this point Creationists, through ID and IC, have fairly brought their arguments into the scientific realm. For this reason evolutionary biologists simply cannot reject the ID argument out of hand without first taking up its challenges. In doing so, they 
strengthen their case. As the evolutionary geneticist $\mathrm{H}$ Allan Orr (1996) says of Behe's book,

the latest attack on evolution is cleverly argued, biologically informed - and wrong.

\section{THE THEISTIC IMPLICATIONS OF IC AND ID}

The hypothesis that ID puts forward is that there are some functions/features which are irreducibly complex the existence of which cannot be explained as an outcome of an evolutionary process. As we have shown, the first problem is that it is hard to find a function or feature which fulfil the criteria of being 'irreducibly' complex. However setting this aside, we can look at the scientific standing of the chain of logic in the argument in that if there were a function/feature which was IC, and for which an evolutionary process was not demonstrable, is it logical to conclude through inference that there must therefore be a Designer who created the thing? In effect, this is a form of dualistic negative deduction in that it rests on substituting ID as the only alternative explanation to evolution. Thus, IC as a hypothesis is really only testable by comparing its ability to explain natural features and processes with evolution's ability to do the same.

Teleologically, IC leads to ID which leads to Creationism. In contrast the relationship between evolution and theism is somewhat less clear. Whilst we do not consider evolution to have atheism as its inevitable end point some scientists such as Dawkins argue that this is precisely where one should end up, and that they themselves are atheist because of the power of evolution to account for the natural world without any reference to deistic intervention. Such a position has also been embraced by some Creationists as a crucially important point for how evolution should be viewed. For example Phillip Johnson, a University of California at Berkeley law professor, has been paraphrased as saying that one must convince people that Darwinism is inherently atheistic, thus shifting the debate from creationism versus evolution to the existence of God vs. the nonexistence of God (Boston 1999).

The teleological process resulting in theism for IC supporters, like Behe or the ID apologist William Dembski means that religion inevitably becomes part of the ID argument and of the evolution argument as well. 


\section{WIDER IMPLICATIONS OF ID FOR SCIENTIFIC KNOWLEDGE}

The arguments about ID have not been confined to the halls of academe or scholarly debate about the natural world. Considerable contention has arisen over the desire by some that ID should be considered an appropriate topic for inclusion in a science education curriculum both at the level of secondary education and higher education. Here we have entering the fray a struggle for ID to have a wider legitimacy. This was illustrated most recently in the Court case of Kitzmiller et al. v. Dover Area School Board (<http://www. pamd.uscourts.gov/kitzmiller/kitzmiller_342.pdf $>$ ) which decided that ID should not be taught alongside evolution in a science class.

Briefly, the case involved parents who challenged the teaching of creationism in the school within the science curriculum. The challenge was based on a potential violation of the First Amendment of the U.S. Constitution (Government will make no ruling respecting the establishment of a religion) and hence the case itself required a ruling on whether ID was science or religion. In his ruling Judge Jones identified three tests of whether ID was science:

we find that while ID arguments may be true, a proposition on which the court takes no position, ID is not science. We find that ID fails on three different levels, any one of which is sufficient to preclude a determination that ID is science. They are: (1) ID violates the centuries-old ground rules of science by invoking and permitting supernatural causation; (2) the argument of irreducible complexity, central to ID, employs the same flawed and illogical contrived dualism that doomed creation science in the 1980's; and (3) ID's negative attacks on evolution have been refuted by the scientific community.

We can see here how the classification of what counts as science in lay terms is slightly different to the debates at a more academic level. First of all, why does ID violate the rules of science by invoking supernatural causation? The key word is 'supernatural'. Doubtless to many believers God does transcend the rules of nature/physics and is not constrained by them in any way. But IDers, by fighting science with science, claim not specifically to mean God as Creator when they invoke ID. However for the Judge the 
association between ID and creationism should not be sidestepped. Furthermore he derives from the material put forward by the expert witnesses in the case for both sides the conclusion that science cannot coupled with theism in its explanations.

We are uncomfortable with this because, just as we think the science/atheism coupling is not necessarily inherent, the scientific argument of ID is also not affected by whether or not deism is involved.

Our understanding of the second point is that there is a logical problem with the way in which ID comes to a conclusion from the evidence of IC. ID derives its claim to be credible as a source of scientific conclusions on the basis that if evolution cannot account for something then it must be God/Intelligent Designer who is the cause. We think this is a fair point, but in itself it is not enough to defeat the ID argument.

To deal with Judge Jones's third point: “ID's negative attacks on evolution have been refuted by the scientific community". In our view, whilst this is the case, we do not see it as precluding a determination that ID is science. Negative attacks on evolution, or rather, forceful debate and testing of evolution, is exactly what evolution needs and what science thrives on. This does however bring into view an ideological mantle that evolution can assume in the hands of some of its proponents. In effect evolution as a hegemonic idea becomes Evolutionism and, along with the tendency for the idea of adaptation to be used in a 'panglossian' way (a coining of Gould \& Lewontin [1979] from the character Dr Pangloss in Voltaire's 'Candide', who believed that 'everything was for the best'), i.e. to become Adaptationism, resulting in it being positioned as some sort of universal truth. While scientists may decry ID as religious ideology, evolution and adaption as Evolutionism and Adaptationism are also ideological in character - what the philosopher Mary Midgely (1996:140) has defined as 'scientism': "the undiscriminating faith in science as...the right way to answer all questions”. Natural selection has been described by philosopher Daniel Dennett as a 'Universal Acid' which can be invoked to explain almost anything (Dennett 1995), eating 'down' through all aspects of biology, and 'up' into culture and society. Adaptationism, although having its critics within science (see Gould and Lewontin 1979), can also be invoked as “A Reason For Everything' (the title of a book by Marek Kohn (2004), on influential British evolutionary 
biologists), with Maynard Smith claiming to have always been an adaptationist, even when reading Kipling as a boy (presumably the 'Just So' stories) (quoted in Kohn 2004). The hegemony of Evolutionism and Adaptationism as explanations of everything challenges Creationism attempting to do exactly the same thing.

There is another of Dorit's 'fallacies' that is a useful next step in our argument: "there is a conspiracy of silence among scientists concerning the failure of Darwinian explanation". The "conspiracy theory' which is rampant in Creationist literature, is one that does the scientific IDers little credit to adopt. Evolutionary biologists have found a theory that, for now, explains better than anything else the diversity of form and function around us. But, like all scientific theories, it is not, and should not, be considered sacrosanct. Despite massive interest in evolution after the publication of The Origin of Species in 1859, support for natural selection (the mechanism of evolution) was lukewarm. Since then evolution has not always had an easy ride from scientists. Dawkins (2003c:80) in an article with the provocative title 'Darwin Triumphant: Darwinism as a Universal Truth', quotes the early $20^{\text {th }}$ century geneticist William Bateson 1913:248):

The transformation of masses of populations by imperceptible steps guided by selection is, as most of us now see, so inapplicable to the fact that we can only marvel...at the want of penetration displayed by the advocates of such a proposition.

Ernst Mayr (1982) provides an historical perspective of the fortunes of Darwinism, prior to what is referred to as the Modern Synthesis of the 1940s (when genetics really began to have an impact on evolutionary theory) which was probably when evolution began to be fully accepted by most biologists, with natural selection as its prime mover. However, a useful example to use against the conspiracy theory creationists is that of the "neutral theory of molecular evolution', developed by Motoo Kimura (1968; 1983). Kimura suggested that random change was more important than natural selection at the molecular level: 'selectively neutral' (no fitness effects) variation in proteins and DNA occurs. At first this theory was deeply unpopular. It was regarded as either entirely wrong, or merely very unimportant. The great evolutionist Ernst Mayr never really accepted it, for example. Now neutral theory can be found in the standard text books. 
These theories are supported not because they bolster evolution, but because, despite initial unpopularity, they are exciting and testable. Paradigms shift or crumble and then what was once revolutionary becomes orthodox. This is how science works. ID, with IC as its chief weapon should be treated in the same way, and, as it argues scientifically, this is how it is treated. There is no conspiracy: it is just that ID fails to convince on a quite fundamental level. Other arguments against evolution, or how we currently understand evolution, are taken on board, discussed, dissected, and either accepted, or thrown out. So far ID is not found acceptable.

And this where we reach a potential conclusion: we would contend that ID and IC (but not under those names) are already a feature of research into evolution. They are a facet of the uncompleted, unanswered questions that we still have about our potentially flawed, certainly incomplete, but best-we-have-for-now theory, with its maybe-most-important-maybe-only-one-of-many mechanisms, natural selection, for explaining the diversity of form and function of life. Each time we raise a question about how evolution, as we currently understand it, works; each time we 'prove' (in the true sense of the word) the powers of natural selection, we are, as scientists, providing support or otherwise for IC and ID. They are enclosed within the whole evolutionary argument; they are valid questions and reservations about the evolutionary thesis. They are also very important, but not the only, foils against the ideologies of Evolutionism and Adaptationism. We would also contend that, useful as they are in that role, they are failing dismally to make a dent in evolution. Judge Jones says this as well, and we agree with him, but as explained above, we emphatically disagree with the Judge when he uses this failure to throw ID out of science. We cannot cheat by using limiting demarcationist arguments to exclude ID and IC from science: all we have to do is continue as objectively as possible in our pursuit of the question of how life evolves or is adapted for its environment. If this means the throwing out of evolution as a valid theory, then so be it: as scientists that shouldn't scare us, but instead excite and intrigue us.

The arguments over the science in ID and IC are ultimately about the meaning of science and the application of the scientific method. In discussions of the explicatory power of science in general and evolution in particular the existence and arguments of ID and IC should certainly be given a place. These arguments already exist 
within the science class, as tests of the hypothetical powers of natural selection, and in the final analysis ID and IC become nonarguments in the ongoing testing of the role of natural selection in evolutionary theory. Intelligent students in science, philosophy and theology will, however, be able to draw their own conclusions, free of dogma and ideology from both sides of the debate.

\section{Consulted literature}

Bateson, W 1913. Problems of Genetics. Oxford University Press: London, 248.

Behe, M 1996. Darwin's Black Box: The Biochemical Challenge to Evolution. New York: The Free Press.

-, 2000. A True Acid Test: Response to Ken Miller <http://www. arn.org/docs/behe/mb_trueacidtest.htm>

Boston, R 1999. Missionary Man TV Preacher D James Kennedy And His Allies Are Targeting Public School Children For Evangelism. Church and State.

$<$ http://web.archive.org/web/20010508032051/www.au.org/churchstate/cs4 995.htm>

Collins, F 2003. Faith and the human genome. 2002 ASA Annual meeting plenary address. Perspectives on Science and Christian Faith. 55,142-153.

$<$ http://www.asa3.org/ASA/PSCF/2003/PSCF9-03Collins.pdf >

Darwin, C 1859. On the Origin of Species by Means of Natural Selection, or The Preservation of Favoured Races in the Struggle for Life. London: John Murray.

Dawkins R 1986. The Blind Watchmaker. London: Longman.

-, 1997. Is Science a Religion? The Humanist. 57(1) (no page numbers).

$<$ http://www.thehumanist.org/humanist/articles/dawkins.html>

-, 2001. Children must choose their own beliefs - an open letter to Estelle Morris. The Observer (U.K.), 30 December 2001. <http://observer. guardian.co.uk/comment/story/0,,625743,00.html>

-, 2003a. What is True? In: The Devil's Chaplain: selected essays by Richard Dawkins. London: Weidenfeld \& Nicolson, 14-19.

-, 2003b. Viruses of the Mind. In: The Devil's Chaplain: selected essays by Richard Dawkins. London: Weidenfeld \& Nicolson, 128-145.

-, 2003c. Darwin Triumphant: Darwinism as a Universal Truth. In: The Devil's Chaplain: selected essays by Richard Dawkins. London: Weidenfeld \& Nicolsonm, 78-90.

-, 2006. The God Delusion. U.K.: Bantam Books.

Dembski, W A 1998. The Design Inference: Eliminating Chance through Small Probabilities. Cambridge University Press: Cambridge. 
Dennett, D 1995. Darwin's Dangerous Idea. New York: Simon \& Schuster.

Dorit, R 1997. A Review of Darwin's Black Box: The Biochemical Challenge to Evolution, by Michael J Behe. American Scientist (September-October 1997).

$<$ http://www.americanscientist.org/template/AssetDetail/assetid/22794?fullt ext $=$ true $>$

Gould, S J 1980. The Panda's Thumb. In: The Panda's Thumb: More Reflections in Natural History. New York: W W Norton, 19-26.

-, 1983. Evolution as Fact and Theory. In: Hen's Teeth and Horse's Toes. New York: W W Norton, 253-262.

-, 1999. Rocks of Ages: Science and Religion in the Fullness of Life. New York: The Library of Contemporary Thought, The Ballantine Publishing Group.

-, \& Lewontin, R C 1979. The spandrels of San Marco and the panglossian paradigm: A critique of the adaptationist programme. Proc. Roy. Soc. B 205, 581-598.

Johnson, P E 1999. The Church of Darwin. Op-Ed Page, Wall Street Journal, August 16, 1999.

$<$ <ttp://www.arn.org/docs/johnson/chofdarwin.htm>

Kimura, M 1968. Evolutionary rate at the molecular level. Nature 217, 624626.

-, 1983. The Neutral Theory of Molecular Evolution. Cambridge: Cambridge University Press.

Kohn, M 2004. A Reason for Everything: Natural Selection and the English Imagination. London: Faber \& Faber.

Mayr, E 1982. The Growth of Biological Thought. Diversity, Evolution, and Inheritance. Cambridge Mass.: Belknap Harvard.

Meyer, S C 2006. Signs of Intelligence, Dallas Morning News, January 29, 2006.

$<$ http://www.dallasnews.com/s/dws/dn/opinion/points/stories/DNmeyer_29edi.ART.State.Edition1.3ec9990.html>

Midgely, M 1996. Utopia, Dolphins and Computers: Problems of Philosophical Plumbing. U.K.: Routledge

Miller, K R 1999. Finding Darwin's God: a Scientist's Search for Common Ground between God and Evolution. New York: Cliff Street Books.

Orr, H A 1996. Darwin versus Intelligent Design (Again). Boston Review, December 1996/ January 1997

$<$ http://bostonreview.net/BR21.6/orr.html>

Paley, W 1802. Natural Theology: Evidences of the Existence and Attributes of the Deity, Collected from the Appearances of Nature. Oxford: Oxford University Press. 
Shermer, M 2005. God \& Evolution: Intelligent Design Theory, George W. Bush \& the Question of God. eSkeptic

$<$ http://www.skeptic.com/eskeptic/05-08-16.html>

Wieland, C 1998. The mousetrap man. Interview with Mike Behe, the mousetrap man Creation 20(3), 17 June.

$<$ http://www.answersingenesis.org/creation/v20/i3/mousetrap.asp >

Wilson, E O 1998. Consilience: The Unity of Knowledge. London: Abacus. 